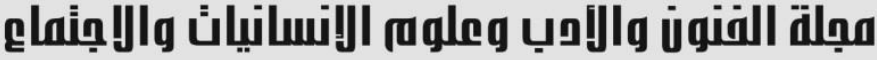 \\ Journal of Arts, Literature, Humanities and Social Sciences \\ www.jalhss.com \\ Volume (54) July 2020 \\ العدد (54) يوليو 2020
}

\section{The Effectiveness of a Proposed Computer Program in Developing the Skill of Oral Expression among Basic Stage Students Who Are Not Arabic Speakers in Denmark (An Experimental Study)}

\author{
Mohammad Mutleq \\ PhD candidate - Curriculum and teaching methods \\ Faculty of education - Al-Madinah International University in Malaysia
}

\section{Ayman Ayed Mohammad Mamdouh}

Associate professor - Faculty of education

Al-Madinah International University in Malaysia

\begin{abstract}
The aim of this research was to identify the effectiveness of a suggested computer program in developing oral expression skills among students of the basic stage of non-Arabic speaking learners in Denmark. The research was based on the design and production of a multimedia-based computer program dedicated to the Arabic language curriculum for the fourth grade، in cooperation with the Granada Educational Foundation in Paris as a research tool. The fourth module was selected to teach its contents and to teach oral expression skills. Besides an achievement test to measure the level of oral expression skills to be applied pre and post over the research sample. The researcher used the experimental method in dealing with the research topic' and measure the effectiveness of the proposed multimedia software program (as an independent variable) in the development of oral expression skill (as a dependent variable). The study sample consisted of two randomly selected groups of fourth level students in the basic stage - one representing the experimental group and the other representing the control group - the number of each (twenty students). The research had revealed a number of findings، the most important of which are: Verifying the effectiveness of employing the suggested multimedia software program in the development of oral expression skills in the fourth level students in the basic stage in Denmark. The research also resulted in statistically significant differences between the average post-test scores of the two groups: experimental and control attributable to the use of the program in teaching oral expression in favor of the experimental group. This means that the program has an impact on the development of oral expression skills in fourth grade students.
\end{abstract}

Keywords: Skill of Oral Expression, Basic Stage Students, Not Arabic Speakers. 


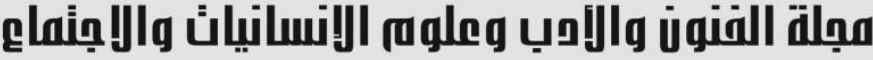 \\ Journal of Arts, Literature, Humanities and Social Sciences \\ www.jalhss.com \\ Volume (54) July 2020 \\ العدد (54) يوليو 2020}

\section{Introduction}

Language is the most subtle manifestation of human activity in which God specializes in human beings, with what God has endowed to man with mental capabilities and devices for speech and speech, which enabled him to develop his language in a way that is more sophisticated and more sophisticated than all other beings. Its kindness to creativity. And its importance for the human being extends to what it achieves for him from many functions that include his mental, cultural, psychological and social aspects, and it is in its practical essence the means by which he seeks to achieve a better life by building a special culture that accumulates and promotes to build a civilization that is translated into the identity of the group to which it belongs.

It is a system of spoken and written phoneme symbols that consist of words, words, phrases, and phrases used to exchange ideas and feelings between members of a homogeneous language group. It is the tool of expression, communication, and interaction between the sender and the receiver in a humane social domain (AlHashemi, 2005).

It is also a basis for social life, and one of the most important necessities, as it is the basis for the existence of communication in this life, and the means for the person to express his needs and desires to manage his affairs of life and satisfy his social characteristic, which is a method of thinking and a system of expression and communication (Abdel Hamid, 2013).

Our era today is the era of the huge information revolution, due to the development of modern means of communication, which has created many topics for dialogue and discussion, and this requires that a person plan and think about what he says, and that he selects his words and ideas accurately, and displays them in a logical and reasonable way, and man cannot possess this skill Except through the intended education and training, which is why many developed countries have tended to teach the art of oral communication in order for the speaker to produce acceptable, persuasive and exciting speech among listeners.

The Arabic language in the basic education stage is one of the important means in achieving the school's functions, because the language is the most important tool for communication and understanding between the student and his environment, and it is the basis for his education, and the language depends on every activity in and outside the school (Al-Naqa et al., 1996).

Oral expression is one of the arts of the Arabic language, and it is one of the most common and used. It is the human way to communicate with others, satisfy his needs and satisfy his desires, express his thoughts and emotions, participate in conversations and discussions, express opinions and comments, and participate in solving problems. Language and its surrounding rules, vocabulary and methods, but it 


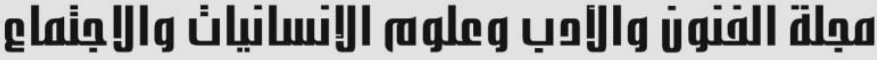 \\ Journal of Arts, Literature, Humanities and Social Sciences \\ www.jalhss.com \\ Volume (54) July 2020 \\ العدد (54) يوليو 2020}

is a means rather than an end, and the goal that aims to teach the language is the correct expression, which must be started to teach and master his skills in ways that are desirable for children with the beginning of their learning in the first classes, in which the child begins learning to read along with the expression through Speaking and exploring, all the way to expressing his simple ideas, with sound polite words (Hawamdeh and Saadi, 2015).

Despite the importance of oral expression and the attention it received, it is noted that there is an apparent weakness in the students' possession of many of their skills in many academic levels, so that their language is not without signs of fatigue, and one of them may stop suddenly before emptying what he wants to say, but rather often Resorting to colloquial language to complete what he was unable to complete with eloquence, some students suffer from a lack of linguistic and intellectual wealth, and they cannot arrange their ideas and link them, this is with the disruption of their style (Khalaf Allah, 2005).

The employment of modern technologies in the academic program for students learning Arabic for non-native speakers contributes to achieving the desired goals of the program, whether they are quantitative or qualitative goals, and overcoming many of the problems facing the program and learners.

This approach is consistent with the outputs and recommendations of the Egyptian Association for Education Technology in the conference between 19971998 in which the association emphasized the need to employ modern technologies, and the need for educational technologies with a strong infrastructure and specialized in the field of education in a way that enables researchers and learners to remain in a permanent and continuous knowledge On the emerging research, studies and educational curricula that allow the employment of modern technologies in the educational field (Al-Gharib, 2001).

Consequently, the process of integrating modern technologies into the educational process has become necessary to keep pace with the tremendous technological developments in all areas of life.

The symposium held in Khartoum in 2009 at the Khartoum International Institute affiliated to the Arab Organization for Education, Culture and Science came out with many recommendations regarding the employment of modern technologies in the field of teaching Arabic to non-native speakers, the most important of which are:

1. The development of computerized software that deals with teaching the Arabic language and is intended for non-Arabic speakers.

2. Opening websites on the Internet to teach Arabic to non-native speakers. 


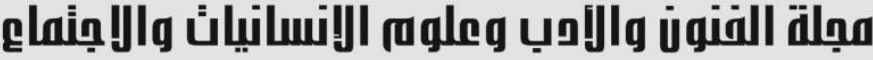 \\ Journal of Arts, Literature, Humanities and Social Sciences www.jalhss.com \\ Volume (54) July 2020 \\ العدد (54) يوليو 2020}

3. Holding training programs for teachers and experts in the areas of dealing with ready software and how to design it, especially those that specialize in teaching Arabic to non-native speakers. (Arab Organization, 2009).

The educational obstacles and problems that the educational process is exposed to require the faculty members to develop their educational methods, including employing modern technical skills in the educational process that in turn will transfer the student from the listener's role to the role of active positive participation, and this matter becomes more necessary if the student is One of the future educational cadres, especially if he was a teacher of the Arabic language for non-native speakers.

Here lies the importance of creating an integrated academic program for students of the Arabic language teaching program for non-native speakers, including using computerized software in the educational process, developing students, and activating the role of modern technologies in communicating information and fixing it in the mind.

There has been a steady increase in recent decades in the provision and employment of educational technologies, so there is no area left in life that has been affected by technological innovations. Many researchers from different countries have paid great attention to the issue of educational techniques in terms of availability, use and obstacles that limit their use in various stages. Similarly, the adoption of technology in the educational process was the focus of attention of researchers in Arab countries, due to their great belief that technological development is the only way to develop the education process.

There have been numerous studies that specialize in employing modern computerized software in the field of teaching the Arabic language in general, and teaching it to non-native speakers in particular. One of these studies is the Al-Masry study (2006), which aimed to know the effectiveness of a multimedia program in developing and retaining written expression skills for eighth graders in the governorates of northern Gaza. The researcher pointed out that employing punctuation marks, using proper linking tools, expressing ideas in useful sentences, employing appropriate evidence, identifying basic and subsidiary ideas, arranging ideas, sequencing and organizing, and selecting appropriate words for meanings were among the most important written expression skills that students acquired during Employment of the multimedia program.

In spite of this, some studies have indicated that the use of computer language teachers in computerized software in education is still modest, and among these studies, the Al-Zahrani study (2007), which indicated that the employment of modern technologies and computerized software for Arabic language teachers did not exceed the use of technologies Basic communication, and did not reach the stage of 


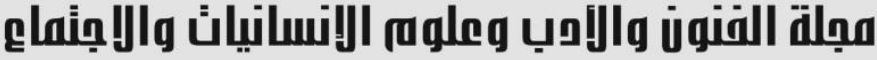 Journal of Arts, Literature, Humanities and Social Sciences www.jalhss.com \\ Volume (54) July 2020 \\ العدد (54) يوليو 2020}

educational software or multimedia or electronic courses or even compact (Zahrani, 2007).

The language greatly exceeds the care, care and attention in any human society, because it plays important roles in the lives of individuals and groups, as it is for the individual a means of acquisition and learning, as it enables him to understand and understand and provides him with knowledge and culture, and develops an idea and provides him with educational attainment, which is in view To the groups is one of the basic foundations, and for the peoples one of the foundations upon which the manifestations of progress and development are built, and some researchers believe that most of the important messages within the groups are transmitted orally.

In addition to the foregoing, the language in general is nothing but the verbal expression in which the individual expresses his thoughts and feelings. The phonetic uses of the language represent a proportion ( 75 to $95 \%$ ) of the total human language uses, and these two ratios are shared by both listening and speaking (Alswerky, 2011). To the extent that a person dominates his expressive abilities, he can express his feelings and opinions clearly and interact with others, and how many people feel lonely and introverted and live on the margins of life, because they do not possess such capabilities or skills that enable them to disclose what is possible in them (Fayoumi, 2012: 254).

Hence the need for an experimental study of the effectiveness of a proposed computer program in developing the skill of oral expression among non-Arabic speaking students in the country of Denmark.

\section{Statement of problem}

There is a growing interest in educational technologies because of their important role in developing the educational process and its role in improving learners' abilities to use information resources.

In order for modern educational technologies to achieve their desired goals, many factors must be available, the most important of which are: the availability of modern educational technologies, and the appropriate competencies of faculty members who are able to employ these technologies in educational programs and motivate them to use and benefit from them in education and self-learning.

This is what modern studies related to the employment of modern educational techniques have indicated in the educational process. In a study conducted by Hassan Zadeh (2012), which aimed to know the extent of the use of modern technology in education, the researcher indicated that there is a great development in the areas of availability and use of modern technologies in education In the past two decades. 


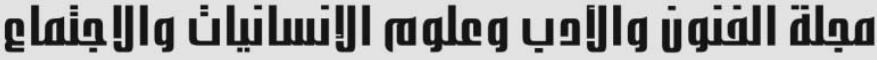 Journal of Arts, Literature, Humanities and Social Sciences www.jalhss.com

Language has a major function in an individual's life, as it facilitates his contact with others, and is his means of gaining knowledge, and the basis for gaining experiences and experiences that make him interact with his community, and learn about the world in which he lives (Fleet, 2002.(

The expression emerges from among the arts of language as an important tool in the transmission of culture and various sciences across successive generations on the path of civilization and humanity that extends throughout the ages, and is considered a means to preserve, transfer and develop the product of the human mind, and from an educational point of view, the student can through expression Ideas and feelings. This expression reflects the student's personality, and many things are discerned from it, such as linguistic strength, rhetorical strength, scientific mastery, sequencing of ideas, and correctness of information (Ismail, 1991)

The researcher has aroused the attention of the researcher through his work as a teacher of the Arabic language for more than fifteen years that there is a linguistic weakness among students at the level of quantity and quality, especially in the basic education stage, as well as the neglect of a number of teachers and their lack of interest in the share of expression like others such as spelling and reading, in addition to the absence of Incentives that encourage students to read free and improve expression.

In light of the position occupied by expression in general, the importance of oral expression is highlighted, because it is the tool for rapid communication between the individual and others, and success in it achieves many vital purposes in different fields. In addition to that the verbal expression is the basis upon which the biblical expression is based, and that success in the biblical expression is not successful if there is no great care given to the verbal expression.

Many studies, such as the study of Miloud (2018) and the study of Muhammad (2008) confirm that oral expression is one of the most important branches of the Arabic language, but rather its goal, because it is a means of understanding, and one of the sides of the process of understanding between individuals, which helps the individual to communicate and communicate with others successfully, Because an individual who can communicate an idea to others with eloquence and ease through a concise, precise phrase, satisfies everyone, so his confidence in himself and his capabilities increases.

Despite the educational importance of verbal expression, there is a clear deficiency in the process of its learning, and this is revealed by some studies that dealt with oral expression such as the study of Abdul Wahab and others (2002), Rahmani (2017), Al-Hashemi (2004)

Al-Bishri (2007) indicated that teaching verbal expression did not reach the required level because there is a general weakness in the level of students in it, as their oral skills are low, and manifestations of weakness are evident in them.

It seems that this deficiency in teaching verbal expression is due to the existence of a number of obstacles that prevent its education from reaching the required level, and for this reason there is an urgent need to know the effectiveness of 


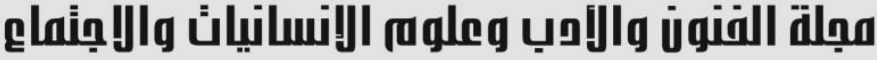 \\ Journal of Arts, Literature, Humanities and Social Sciences www.jalhss.com \\ Volume (54) July 2020 \\ العدد (54) يوليو 2020}

a proposed computer program in developing the skill of oral expression among nonArabic speaking students in the basic stage in government schools That teaches the Arabic language in the country of Denmark.

\section{Research questions}

This research focuses on the effectiveness of a proposed computer program in developing oral expression skills among basic stage students who do not speak Arabic, and thus determines the problem of study in answering the following main question:

What is the effectiveness of a proposed computer program in developing oral expression skills among basic stage students who are not speaking Arabic in Denmark?

The following main question is divided into the following sub-questions:

1. What are the oral expression skills suitable for students of the fourth level in the basic level who are not speaking Arabic in the country of Denmark?

2. What is the proposed computer program for developing oral expression skills among non-Arabic speaking primary school students in basic schools of the Danish Ministry of Education?

3. What are the principles and procedures for the proposed program for developing oral expression skills among non-Arabic speaking primary school students in basic schools of the Danish Ministry of Education?

4. Are there statistically significant differences at the level of significance (0.05) between the mean scores of the experimental group that studied the proposed computer program based on multimedia, and the scores of their peers in the control group in the post-application of the achievement test?

\section{Research objectives}

The current study aims to identify the effect of using the computerized program on the achievement of non-native speakers of Arabic language in the oral expression course, by arriving at the following:

1. Identify the skills of oral expression appropriate for students of the fourth level in the basic stage of non-Arabic speaking in the State of Denmark.

2. Design and production of a proposed computer program for developing oral expression skills for non-Arabic speaking primary school students in basic schools of the Danish Ministry of Education. 


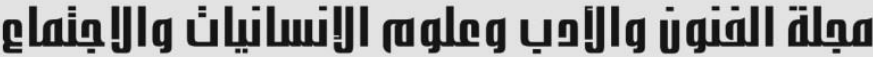

Journal of Arts, Literature, Humanities and Social Sciences www.jalhss.com

Volume (54) July 2020

العدد (54) يوليو 2020

3. Laying the foundations and procedures for the proposed program for developing oral expression skills for non-Arabic speaking primary school students in basic schools of the Danish Ministry of Education.

4. The detection of the presence of statistically significant differences at the level of significance (0.05) between the mean scores of the experimental group that studied the proposed computer program based on multimedia, and the degrees of their peers in the control group in the post-application of the achievement test.

\section{Research significance}

The research results may be useful for:

- Directing the attention of those in charge of preparing curricula when developing Arabic curricula for non-native speakers in Denmark or Europe, or when developing plans and programs that contribute to improving the linguistic performance of pupils, through the research tools and proposed program offered by the research, clarifying the role of the media-based program Multiple skills in developing oral expression skills for fourth grade students.

- Arabic language teachers may benefit non-native speakers in Denmark and Europe by providing them with new ways of teaching the Arabic language, from which it is hoped to make a qualitative change in the teaching of expression and to acquire appropriate oral expression skills for fourth-grade primary students.

- It can be useful for instructors of Arabic language teachers for non-native speakers when holding educational training workshops to train them on educational programs and appropriate methods for teaching oral expression.

The results of the study can open the door for graduate students and researchers in the field of teaching Arabic to non-native speakers in general, and teaching oral expression in particular, to conduct similar research and studies.

- It may constitute an objective response to what educators advocate the importance of keeping pace with modern trends in education, and in line with educational recommendations to care for oral expression skills as basic skills in language teaching and experimenting with methods and models that may lead to positive outcomes in the educational process.

\section{Research definitions}

- The program: The program is defined as the general plan that is set earlier on the processes of education and teaching, at a stage of education, and summarizes the procedures and topics during a specific period, and also includes educational experiences that learners must acquire in an 


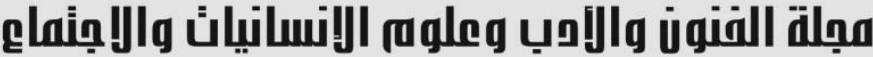

Journal of Arts, Literature, Humanities and Social Sciences

www.jalhss.com

Volume (54) July 2020

العدد (54) يوليو 2020

arrangement in line with their years of development, their needs and their own demands (Al-Naqa, 1996).

- As for procedurally, it is short and sequential units that constitute an educational system with goals, content, teaching aids, and specific evaluation methods related to teaching oral expression skills among fourthgraders.

- Skill: Doing the perfect thing knowledgeable and experienced, within the limits of appropriate costs (time, effort, and money).

- Oral expression: it is the spoken words in which the speaker expresses himself and reflects the feelings and feelings he has in his mind, and what his mind abounds in opinion or thought, and what he wants to provide other information or so in fluency and flow with correctness in the expression And safety in performance (Muhammad, 2008)

- As for procedural, what is meant by verbal expression is the words that the fourth non-Arabic-speaking students express the thoughts, feelings and feelings they have in their souls, or what they want from thoughts and information with a expressive voice, clear ideas and sound language.

- Oral Expression Skill: It is a system of processes that express the learner's ability to express his feelings, feelings, and needs, verbally and effectively.

- As for procedural: it is the level of mastery of non-native speakers of Arabic language from fourth-grade primary students to express themselves in relation to the questions of the oral expression test presented in this study, and it is measured by the degree that the student gets in the pre and post achievement test.

- Effectiveness: The term effectiveness in experimental educational studies as mentioned by (Shehata, Al-Najjar: $(230,2003)$ ) expresses the "extent of the effect that experimental treatment can make as an independent stimulus in one of the dependent variables and it appears in the amount and type of learning achieved through educational situations inside and outside the classroom."

- Effectiveness procedurally: The researcher defines the efficacy as: the ability of the computer program to make a positive impact in developing oral expression skills and is measured by the average score the student obtains in the oral expression test prepared by the researcher.

- Program effectiveness: It is the extent of the impact of the multimediabased computer program on developing oral expression skills for nonArabic speaking fourth-graders in public schools in Denmark. 


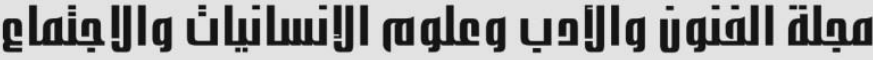 \\ Journal of Arts, Literature, Humanities and Social Sciences \\ www.jalhss.com \\ Volume (54) July 2020 \\ العدد (54) يوليو 2020}

\section{Previous studies}

1. Al-Smadi Study (2018) Which aimed to know the impact of a computerized program to develop oral expressive language skills among children with learning difficulties, and to achieve the goals of the study, the researcher prepared a computerized program aimed at developing oral expressive language skills among students with learning difficulties. The sample of the study consisted of 30 male and female students who were divided into two equal groups, one experimental group subjected to the computerized program and another control group that received training in the traditional way. The study used the quasi-experimental approach. The data were analyzed using the ANCOVA co-analysis, where the results showed that there were statistically significant differences in favor of the experimental group in developing oral expressive language skills. The results also showed the presence of statistically significant differences attributable to the variable of the academic level (grade), while the results showed the presence of statistically significant differences attributable to the gender variable and in favor of females. The study recommended that teachers use the computerized program to develop the oral expressive language for people with learning disabilities.

2. The Study of Khalaf Allah and Al-Ghazzi (2016) Which aimed to design a program using the computer to improve the level of oral expressive language among students with learning difficulties in the elementary stage for grades (third and fourth). An oral expression scale and a computerized training program were prepared after ascertaining the characteristics of these psychometric tools that were applied to the study sample that they faced (20) Of the third and fourth graders, they were chosen by stratified randomness. The results revealed that the oral expression of female students with learning difficulties for the third and fourth grades decreased, and the effectiveness of the computer program used to improve the level of oral expressive language with a statistically significant degree in the level of improvement between the mean levels of oral expression among students with learning difficulties in the third and fourth grades within the experimental group according to Descriptive level variable.

3. Abu Radhia Study (2013) Which aimed to know the impact of children's stories on the development of some creative oral expression skills for fourth-grade students, and the researcher used the experimental approach, where the study sample consisted of (64) male and female students who were chosen male and female students, where the experimental group was studied by children's stories, while it studied The control group was the usual method, and a note card and an oral test were used in oral expression skills. The results 


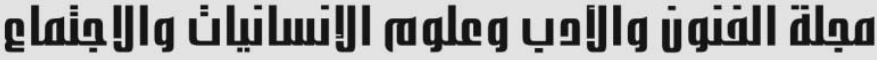 Journal of Arts, Literature, Humanities and Social Sciences www.jalhss.com

indicated that there are statistically significant differences between the mean scores of the experimental group and the control group in the post application due to employing children's stories in creative oral expression skills and in favor of the experimental group.

4. Al-Swairki Study (2005) that aimed to know the effect of using a program based on linguistic games on developing language structures and oral expression skills among fourth grade primary students in Jordan. The researcher randomly selected one of the government basic schools affiliated to the Directorate of Education for the First District of Irbid, and the choice was made on Omar Al Mukhtar Elementary Boys School. Two divisions were randomly chosen from this school. One of them was the experimental group and consisted of (42) students, the training program was applied to it, and the other represented the control group and its strength (42) students, the training program was applied to it, and the other represented the control group and its number (42) students were taught according to the method Prevailing.

The research tool consisted of the training program, the language synthesis test, and the criterion for evaluating performance in oral expression. The validity and reliability indicators for these tools were extracted. After the students 'scores were recorded on the pre and post tests, the appropriate statistical analysis was conducted on them, and the study found that there was a statistically significant difference between the experimental and control groups in acquiring the language structures and the oral expression skills in favor of the experimental group that studied the language structures using the language games method. The results of the study also revealed a positive correlation between the acquisition of linguistic structures and oral expression skills among students.

5. Al-Qalamji Study (2015) Which aimed to know the effectiveness of an educational program based on listening skills in developing oral expression for fifth grade primary school students, and the researcher followed the experimental approach. The number of the study members was (40) male and female students, distributed into two groups in each group (20) male and female students, an experimental group and a control group, whereby the experimental group was studied by means of the listening program, while the control group was studied by the usual method. The results of the study revealed that the degree of fifth-grade students possessing the skills of oral expression was medium, and that the method of teaching according to the listening-based educational program was effective in developing oral expression skills among fifth-grade primary students, where the experimental group students who studied through the educational program exceeded 


\section{مجالة الفiون والأوب Journal of Arts, Literature, Humanities and Social Sciences www.jalhss.com \\ Volume (54) July 2020 \\ العدد (54) يوليو 2020}

Students of the control group who studied in the usual way on the post-test statistically.

6. The Study of Edema (2014) That aimed to know the impact of the use of motion pictures on developing language expression skills among fourthgrade primary students in the governorates of Gaza, and the researcher used the experimental approach, and the study sample included (72) students who were randomly chosen, and they were divided into two groups, the first experimental and their number (38) Male and female students, who studied by motion picture, and the second is a number of its members (34) male and female students, studied by experimental method. The results indicated that there were statistically significant differences between the mean scores of the experimental group and the mean scores of the control group in the postselection and in favor of the experimental group that was studied by means of moving pictures.

\section{Research methodology}

\section{Designing the research instruments}

- Content Analysis Tool of the fourth grade Arabic curriculum Oral Expression Skills Test.

\section{Content Analysis Tool of the fourth grade Arabic curriculum}

The researcher analyzed the content of the accessible Arabic textbook for the fourth basic grade to determine the oral expression skills included in it. The content analysis means: "A method or tool for scientific research that researchers can use in a variety of research fields to describe the apparent content and explicit content of the material being analyzed, or to discover the cultural, intellectual, political or ideological background of the owners of the materials to be analyzed" (Al-Shammas, 2011, 133) The analysis process seeks to achieve three goals:

1. It mainly contributes to defining the teaching objectives.

2. It helps in choosing teaching strategies and teaching aids, as each type of content has what is appropriate for it from those strategies or means in clarifying it.

3. Contributes to the selection of evaluation tools, for each content category has what it suits from such tools (Olives, 1999, 145 .(

4. The analysis should also be characterized by several specifications, including:

5. Objectivity: It means that the analyst rejects his / her own assessment during the inventory of text components.

6. Inclusivity: It is intended that the analyst not neglect any aspect of the text.

7. Methodology: its meaning, subjecting the analysis to known standards, and clear steps. If another person came to repeat the analysis, he reached the same results as the first analyst. 


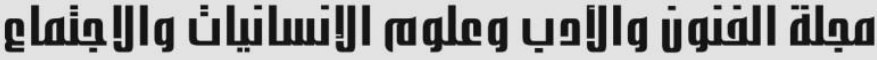 \\ Journal of Arts, Literature, Humanities and Social Sciences \\ www.jalhss.com \\ Volume (54) July 2020 \\ العدد (54) يوليو 2020}

8. Quantity: It means that the analysis be quantitative, to enable measurable estimates to be reached, meaning that the result is numbers that include frequencies (Ammar, 1999, p. 160.(

9. Since the content analysis is a systematic research, it includes a set of methodological steps that the researcher has followed closely to reach the desired results. These steps can be identified with the following:

Knowledge acquired from references and previous studies that addressed oral expression skills:

Including the Othman and Rababah study (2015), and the Mukahli study (2015)

- Determine the objective of the analysis

The primary goal of analyzing the content of the accessible Arabic textbook for the fourth basic grade is to identify the skills of oral expression included, and to design research tools through it.

\section{- Derive the list of oral expression skills by:}

-A survey of the opinions of some fourth-grade teachers in Denmark about the skills of oral expression for the fourth grade, by asking an open question to a sample of them amounting to 6 teachers: (What are the skills of oral expression to be taught to the fourth grade students in Denmark?)

-Various references and books on methods of teaching Arabic to non-native speakers. -Previous studies and research conducted on the subject of oral expression.

\section{Finalizing the list:}

Some adjustments were made to the skills list based on the recommendations of the arbitrators, as the skills were divided into four main aspects, namely: the linguistic side, the audio side, the aspect (i.e. body language), and the intellectual side. Some of the skills were also deleted:

Avoid stuttering, stinging, and being lost.

-Giving meaning to the vocabulary with reference and representation.

-Using knowledge to suit the topic.

-Completion of the sentence corners of the useful word.

-Moving the members of his body according to the meaning.

-Speak fluently.

Thus, the list of oral expression skills for the fourth grade in the final form became composed of four main skills. Under each major skill, sub-skills are included (Table $1)$ : 


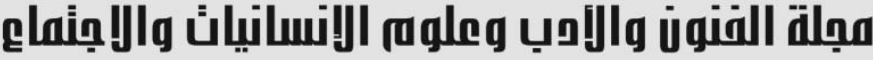

Journal of Arts, Literature, Humanities and Social Sciences

www.jalhss.com

Table (1): The final version of the list of oral expression skills for the fourth grade

\begin{tabular}{|l|l|}
\hline Number & \multicolumn{1}{c|}{ First: the linguistic aspect } \\
\hline 1 & Completes the pillars of the sentence \\
\hline 2 & It uses appropriate vocabulary for meaning \\
\hline 3 & Employ appropriate language structures \\
\hline 4 & It uses the appropriate fastening tools \\
\hline 5 & The scene is expressed in sound language \\
\hline \multicolumn{2}{|c|}{ Second: the sound aspect } \\
\hline 6 & Speaking with a clear voice \\
\hline 7 & He speaks fluently and with appropriate speed \\
\hline 8 & It takes into account the points of connection and stop \\
\hline 9 & Vary in vocal performance according to meaning \\
\hline 10 & Expresses ideas clearly \\
\hline 11 & Arrange and chain ideas \\
\hline 12 & The topic shall be concluded with an appropriate conclusion \\
\hline \multicolumn{2}{|l|}{ Fourth: The Milestones } \\
\hline 13 & Uses facial expressions according to the meaning expressed \\
\hline 14 & Confront audiences confidently and audaciously without confusion \\
\hline 15 & Take the right moderate stance \\
\hline
\end{tabular}

10. Specifying the sample of the analysis: The sample of the analysis was the content of the accessible Arabic textbook for the fourth basic class of non-Arabic speakers in Denmark, which is illustrated in the following table:

Table (2) Description of the analysis sample: The content of the accessible Arabic textbook for the fourth basic class, non-Arabic speakers in Denmark

\begin{tabular}{|c|c|c|}
\hline Number of pages & Number of lessons & Book \\
\hline 5 & My beautiful language & \multirow{12}{*}{$\begin{array}{l}\text { the accessible Arabic textbook } \\
\text { for the fourth basic class }\end{array}$} \\
\hline 5 & Computer & \\
\hline 5 & We must cooperate & \\
\hline 5 & Eid celebration & \\
\hline 2 & School poem & \\
\hline 5 & Thank you both & \\
\hline 5 & The humble prince & \\
\hline 5 & At the barbershop & \\
\hline 5 & The fire & \\
\hline 2 & My mom's poem & \\
\hline 5 & The little knight & \\
\hline 5 & A train trip & \\
\hline
\end{tabular}




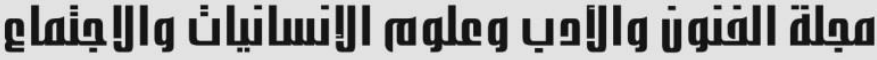 \\ Journal of Arts, Literature, Humanities and Social Sciences www.jalhss.com

\begin{tabular}{|c|c|}
\hline 5 & At te camp \\
\hline 2 & Poem verses ability \\
\hline
\end{tabular}

\section{Determining the controls of the analysis process:}

The analysis process included the following:

The content of the accessible Arabic textbook for the fourth basic grade.

-Pictures and accompanying questions in the analysis process.

-The questions presented at the end of each lesson.

-All activities mentioned in the book.

-Teaching aids used in the course of presenting each lesson.

\section{Ensure the accuracy of the analysis}

To verify the sincerity of the analysis process, two arbitrators with expertise in the field of content analysis were hired, where they were provided with a list of the previous analysis attached with a copy of the analysis form to write their observations about their suitability for analysis with any proposed amendments, and the judges agreed on the tool.

\section{Ensure that the analysis is consistent}

To ensure the consistency of the analysis, I selected three lessons from the main analysis sample, based on the validity of the tests.

The researcher has conducted an analysis of the content of the three chosen lessons from the Arabic textbook for the fourth grade basic, then he used two other colleagues who have knowledge of the foundations of the analysis and knowledge of the research objectives, to do an analysis of the content of the chosen lessons after the researcher explained to them the method of analysis and its controls.

The number of paragraphs of the analysis in the three lessons of the accessible Arabic book for the fourth basic grade (12) items, and the following tables show the agreement ratios and the percentages of the coefficient of the analysis between the researcher's analysis and each of the analysts 'analysis, and between the first and second analysts' analysis.

Table (4) the percentages of the coefficient of analysis between the researcher's analysis and the analysis of the first analyst

\begin{tabular}{|c|c|c|c|c|c|}
\hline \multirow{2}{*}{$\begin{array}{c}\text { Analysis } \\
\text { class }\end{array}$} & \multicolumn{2}{|c|}{ Frewuencies } & Frequencies \\
angearcher & $\begin{array}{c}\text { Second } \\
\text { analysis } \\
\text { analyst } \\
\text { analysis }\end{array}$ & $\begin{array}{c}\text { Frequencies } \\
\text { two analyzes } \\
\text { that are } \\
\text { disputed in } \\
\text { the two } \\
\text { analyzes }\end{array}$ & $\begin{array}{c}\text { Percentage } \\
\text { of stability } \\
\text { factor } \\
\text { values }\end{array}$ \\
\hline $\begin{array}{c}\text { Oral } \\
\text { expression } \\
\text { skills }\end{array}$ & 12 & 14 & 12 & 2 & 0,923 \\
\hline
\end{tabular}

Agreement $=12 / 14=0.86$ 


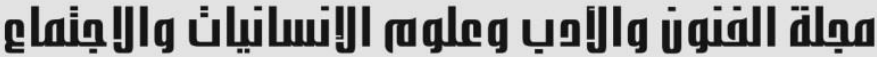

Journal of Arts, Literature, Humanities and Social Sciences

www.jalhss.com

Volume (54) July 2020

العدد (54) يوليو 2020

Table (5) the percentages of the coefficient of analysis between the researcher's analysis and the analysis of the second analyst

\begin{tabular}{|c|c|c|c|c|c|}
\hline \multirow{2}{*}{$\begin{array}{l}\text { Analysis } \\
\text { class }\end{array}$} & \multicolumn{2}{|c|}{ Frequencies } & \multirow{2}{*}{$\begin{array}{l}\text { Frequencies } \\
\text { agreed in the } \\
\text { two analyzes }\end{array}$} & \multirow[b]{2}{*}{$\begin{array}{l}\text { Frequencies } \\
\text { that are } \\
\text { disputed in } \\
\text { the two } \\
\text { analyzes }\end{array}$} & \multirow{2}{*}{$\begin{array}{c}\text { Percentage } \\
\text { of stability } \\
\text { factor } \\
\text { values }\end{array}$} \\
\hline & $\begin{array}{c}\text { Researcher } \\
\text { analysis }\end{array}$ & $\begin{array}{c}\text { Second } \\
\text { analyst } \\
\text { analysis }\end{array}$ & & & \\
\hline $\begin{array}{l}\text { Oral } \\
\text { expression } \\
\text { skills }\end{array}$ & 12 & 13 & 12 & 1 & 0,96 \\
\hline
\end{tabular}

agreement $=13 / 12=0,923$

Table (6): percentages of the analysis reliability between the first and second analyses

\begin{tabular}{|c|c|c|c|c|c|}
\hline \multirow{2}{*}{$\begin{array}{c}\text { Analysis } \\
\text { class }\end{array}$} & \multicolumn{2}{|c|}{ Frequencies } & \multirow{2}{*}{$\begin{array}{l}\text { Frequencies } \\
\text { agreed in the } \\
\text { two analyzes }\end{array}$} & \multirow{2}{*}{$\begin{array}{c}\text { Frequencies } \\
\text { that are } \\
\text { disputed in } \\
\text { the two } \\
\text { analyzes }\end{array}$} & \multirow{2}{*}{$\begin{array}{c}\text { Percentage } \\
\text { of stability } \\
\text { factor } \\
\text { values }\end{array}$} \\
\hline & $\begin{array}{l}\text { Researcher } \\
\text { analysis }\end{array}$ & $\begin{array}{c}\text { Second } \\
\text { analyst } \\
\text { analysis }\end{array}$ & & & \\
\hline $\begin{array}{c}\text { Oral } \\
\text { expression } \\
\text { skills }\end{array}$ & 14 & 13 & 13 & 1 & 0,963 \\
\hline
\end{tabular}

agreement $=14 / 13=0,928$

It is noted from the previous tables that agreement ratios and percentages of stability parameters between researcher analysis and analysis of analysts, and analysis of first and second analysts are good and sufficient to ensure confidence in the stability of the analysis.

After the researcher verified the validity and reliability of the analysis tool, he analyzed the content of the three lessons (at the barber, the fire, my mother's poem) from the accessible Arabic textbook for the fourth grade, and the following table shows the results of the analysis process.

Table (7) Results of the analysis of the content of the three lessons (when the barber, the fire, my mother's poem) from the Arabic textbook for the fourth grade basic

\begin{tabular}{|c|c|c|c|}
\hline Number & Oral expression skill & Frequency & Percentage \\
\hline 1 & $\begin{array}{c}\text { Selecting ideas appropriate for the subject of oral } \\
\text { expression }\end{array}$ & 2 & $\% 5.71$ \\
\hline 2 & The sequence of ideas and their interconnectedness & 4 & $\% 11.43$ \\
\hline 3 & Voice toning when expressing & 2 & $\% 5.71$ \\
\hline 4 & Consolidate ideas with evidence and evidence & 1 & $\% 2.85$ \\
\hline 5 & The choice of terms expressing meaning & 5 & $\% 14.30$ \\
\hline
\end{tabular}




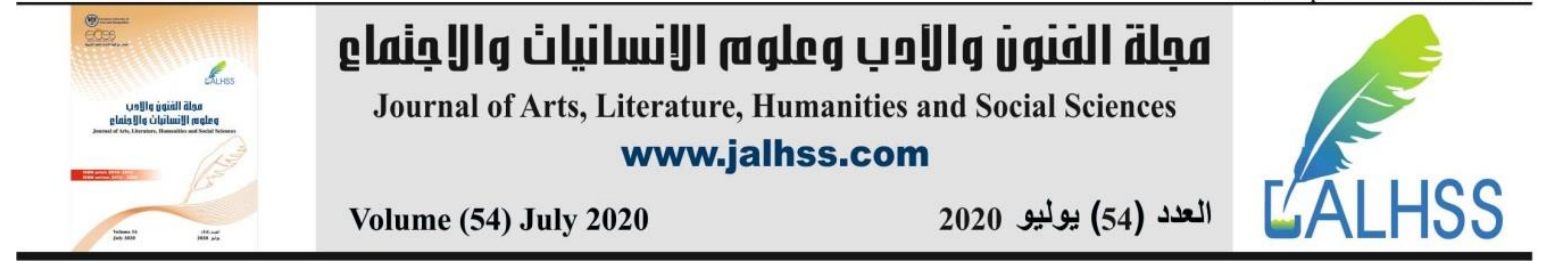

\begin{tabular}{|c|c|c|c|}
\hline 6 & Non-repeated words & 1 & $\% 2.85$ \\
\hline 7 & Use the appropriate strapping tools & 4 & $\% 11.43$ \\
\hline 8 & Use appropriate times for verbs & 4 & $\% 11.43$ \\
\hline 9 & Use appropriate pronouns and reference names & 5 & $\% 14.30$ \\
\hline 10 & Take out the letters from their correct exits & 4 & $\% 11.43$ \\
\hline 11 & $\begin{array}{c}\text { Aligning the speed of speech with the attention of } \\
\text { listeners }\end{array}$ & 1 & $\% 02.85$ \\
\hline 12 & The employment and clarity of the sound apparatus & 2 & $\% 5.71$ \\
\hline \multicolumn{2}{|c|}{ Total } & 35 & $\% 100$ \\
\hline
\end{tabular}

The previous table shows us that the number of analysis paragraphs reached 35 items, and they were distributed among the categories of analysis represented by the skills of oral expression as follows: The skills (choice of expressions of meaning, the use of pronouns and appropriate reference names) occupied the first rank with a relative weight of (14.30\%), then Skills (using connectivity tools, sequencing ideas and their interconnection, using appropriate times for verbs, extracting letters from their correct exits) in second place with a relative weight (11.43\%), then skills (selecting appropriate ideas for the subject of oral expression, vocal toning when expressing, employing the vocal apparatus and clarity ) Is ranked third with proportional weight Value (5.71), and finally the skills of (strengthening the ideas of examples and evidence, not to repeat the words, alignment between the modern and the speed of the attention of the audience) with a relative weight value $(2.85 \%$.(

Based on these findings on the analysis of the content of the three lessons from the accessible Arabic textbook for the fourth basic grade, and also based on the opinions of the arbitrators, the top three skills were obtained with the highest percentage and the arbitrators agreed on them, namely (the choice of expressions of meaning, the use of pronouns and appropriate reference names, Use of interconnection tools, sequencing and interconnection of ideas, use of appropriate times for verbs, output of letters from their correct outputs, selection of ideas appropriate for the subject of oral expression, vocal tone when expressing, employing the vocal apparatus and clarity), for inclusion in the proposed computer program, etc. Her match in the oral expression skills test designed by the researcher.

\section{Oral expression skills test}

- The researcher relied on the design and construction of the oral expression test on several stages that are planned and organized according to the rules for designing and building tests before finalizing it, and these stages are: 


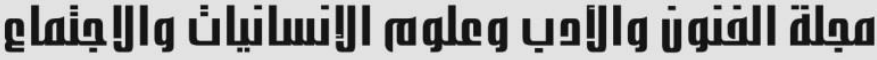 \\ Journal of Arts, Literature, Humanities and Social Sciences \\ www.jalhss.com \\ Volume (54) July 2020 \\ العدد (54) يوليو 2020}

\section{Determine the overall goal of the test}

This test aims to measure the oral expression skills of basic fourth-grade nonArabic speakers in Denmark.

Seeing previous research and studies that dealt with oral expression skills, with the aim of benefiting from the steps taken in building and applying the test, and from these studies: Al-Muhammadi Study (2013), Mukahli (2015), and Nasr and Al-Abadi Study (2005), as well as some references related to Relevance to oral expression skills.

\section{Determine test specifications and vocabulary type}

After reviewing the previous studies, the researcher prepared a specifications table that shows the relative weights and the number of test items for each of the three lessons.

\section{Placement of oral expression test instructions}

The researcher has developed test instructions that include special information that shows the goal of the oral expression skills test, the number of test items, and the time allotted to answer the test.

\section{Preparing the oral expression skills test in its initial form}

After identifying nine skills of oral expression skills that can be developed by fourthgrade primary students who do not speak Arabic in Denmark in the Arabic language subject, and after analyzing the three lessons (at the barber, the fire, my mother's poem) from the Arabic textbook, the researcher built a diverse test items It includes skills (choice of verbal expressions of meaning, use of pronouns and appropriate nouns, use of binding tools, sequencing and coherence of ideas, use of appropriate times for verbs, output of letters from their correct exits, selection of appropriate ideas for the subject of oral expression, phonological toning when Expression, placement and clarity of the sound device)

In formulating the test items, the researcher considered the following matters:

a. Language integrity and accuracy.

B. To be specific and clear is not vague.

T. Suitable for the scientific and age level of learners.

D. Linked to the topics learned by the learners.

C. Linked to students' lives, observations, and experiences.

Consequently, the test consisted of (39) questions, distributed almost equally among the nine skills. 


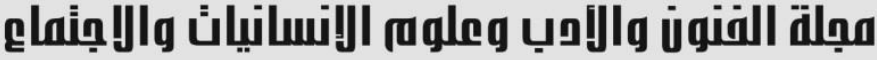 \\ Journal of Arts, Literature, Humanities and Social Sciences \\ www.jalhss.com \\ Volume (54) July 2020 \\ العدد (54) يوليو 2020}

\section{Determining the positions of oral expression}

- In order for the researcher to observe learners' performance in oral expression and measure their skills during it, the researcher chose two areas for oral expression:

- First: the interview

- The interview contributes to breaking the barrier of fear of the expression of the learner, and gives it a motivation towards expression, and it also gives indications of how the learner adapts to his interlocutor (the teacher or his colleague.(

- Second: the style of discussion and dialogue

- This method contributes to discovering the strengths and weaknesses of the learners in the skills of oral expression, where it is left for the learners to discuss each other in the contents of the images presented in front of them and express an opinion in their answers.

\section{Verify the veracity and reliability of the oral expression skills test}

The validity of the test was verified by presenting it to a group of arbitrators who specialize in curriculum and teaching methods, psychology, measurement and evaluation, in order to poll their views on the validity of each of:

Number of test items.

Language integrity in drafting.

-The suitability of the content of each item to the skill it represents.

Validity of the test for measuring oral expression skills.

-The suitability of the test items to learners' levels.

-Adding other notes that the arbitrators deem necessary.

After the arbitrators expressed their opinion on the test clauses, the researcher responded to their opinions, and implemented the necessary deletion, amendment and addition, as shown in the following table:

Table (9): Examples of some amended items and some added instructions according to the opinions of the arbitrators to test oral expression skills

\begin{tabular}{|c|c|}
\hline Item & $\begin{array}{c}\text { Adjustment in progress } \\
\text { Replace the image of a boy who cuts his hair with the } \\
\text { image of cleaning tools }\end{array}$ \\
\hline $14+13+12$ & $\begin{array}{c}\text { Replace a special image of the fire lesson with the image } \\
\text { of the butcher }\end{array}$ \\
\hline 20 & .Replace the fire truck as it is running on snow with snow \\
\hline $16+15+14$ & Deletion \\
\hline 32 & addition \\
\hline
\end{tabular}




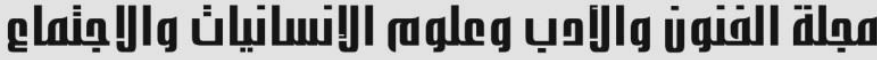 Journal of Arts, Literature, Humanities and Social Sciences www.jalhss.com

Thus, the test became in its final form consisting of (32) questions distributed over nine skills.

\section{The pilot study for the Arabic language achievement test}

The test was applied to an exploratory sample of (18) students from the fourth primary class, who were chosen from outside the study sample from "Abu bin Kaab" school, in the second week of October of the academic year 2017-2018, then re-test after 15 days of The first date.

\section{Calculating the test reliability}

The researcher has calculated the stability of the test by applying and reapplying the method, as this idea of this method is based on taking the test on a group of individuals and then re-conducting the same test on the same group of individuals after a period of time and so each individual gets a score in the first procedure of the test and on another degree in The second procedure for testing, and when we monitor these scores and calculate the coefficient of correlation of the first time scores with the second time scores, we get the coefficient of test stability.

The reliability coefficient of the test was calculated in this way with an interval of two weeks, on a reconnaissance sample of 18 individuals, and the researcher tried to repeat the application in the same conditions as the first application. Pearson correlation coefficient was calculated between the results of the two applications, and the correlation coefficient was equal to (0.93), which is a high coefficient. The following table shows the stability coefficient of the oral expression skills test for the fourth grade.

Table (10): Stability coefficient of the Oral Expression Skills test for fourth grade students

\begin{tabular}{|c|c|c|c|}
\hline Scale & $\begin{array}{c}\text { Participants } \\
\text { number }\end{array}$ & $\begin{array}{c}\text { Reliability } \\
\text { coefficient }\end{array}$ & Sig \\
\hline Oral expression skills test & 18 & 0.93 & 0.01 \\
\hline
\end{tabular}

10. It is clear from the above table that the test stability coefficient is a positive correlation coefficient and denotes at the significance level 0.01 , which indicates the stability of the test

\section{Standard for assessing the adequacy of learners in oral expression skills (possession levels):}

The note card prepared in this research consists of fifteen items distributed over four main skills. The total score of the note card is determined by seventy-five degrees, where the high degree reflects the high level of oral expression skills of the learner, and the low score reflects the decrease of his oral expression skills. The researcher adopted the method of sales, as the degree that is less than the mid-level (50\%), that is, less than the degree 37.5, was considered a function of a low level of possessing oral expression skills. As for the degree that ranges between the second spring (50\%) 


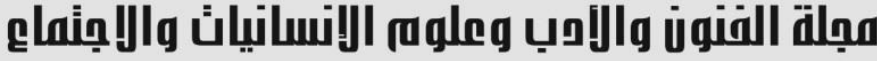

Journal of Arts, Literature, Humanities and Social Sciences

www.jalhss.com

Volume (54) July 2020

العدد (54) يوليو 2020

and less than the third spring (75\%), that is, it falls below the 56.25 degree, it indicates an intermediate level of degree of having oral expression skills, meaning that it is the degree that ranges between 37.5 and less than 56.25. As for the degree that ranges between the third spring and the higher degree (56.25 - 75), it indicates a high level of possession of oral expression skills (Table 11.(

Table (11): The criterion of assessing the adequacy of learners in oral expression skills

\begin{tabular}{|l|l|l|l|l|l|l|}
\hline Oral expression skills & $\begin{array}{l}\text { The } \\
\text { lower } \\
\text { degree }\end{array}$ & $\begin{array}{l}\text { The higher } \\
\text { grade }\end{array}$ & Cut degree & \multicolumn{3}{|c|}{ Level } \\
\hline $\begin{array}{l}\text { Skills related to the aspect } \\
\text { (body language( }\end{array}$ & 3 & 15 & 7.5 & $\begin{array}{l}\text { Less than } \\
7.5\end{array}$ & $\begin{array}{l}-7.5 \text { less } \\
\text { than } \\
11.25\end{array}$ & $15-11.25$ \\
\hline Intellectual skills & 3 & 15 & 7.5 & $\begin{array}{l}\text { Less than } \\
7.5\end{array}$ & $\begin{array}{l}-7.5 \text { less } \\
\text { than } \\
11.25\end{array}$ & $15-11.25$ \\
\hline $\begin{array}{l}\text { Skills related to the audio } \\
\text { aspect }\end{array}$ & 4 & 20 & 10 & $\begin{array}{l}\text { Less than } \\
7.5\end{array}$ & $\begin{array}{l}-7.5 \text { less } \\
\text { than } \\
11.25\end{array}$ & $20-15$ \\
\hline $\begin{array}{l}\text { Skills related to the linguistic } \\
\text { aspect }\end{array}$ & 5 & 25 & 12.5 & $\begin{array}{l}\text { Less than } \\
12.5\end{array}$ & $\begin{array}{l}-12.5 \\
\text { Less than } \\
18.75\end{array}$ & $25-18.75$ \\
\hline Total & 15 & 75 & 37.5 & $\begin{array}{l}\text { Less than } \\
37.5\end{array}$ & $\begin{array}{l}-37.5 \\
\text { less than } \\
56.25\end{array}$ & $75-56.25$ \\
\hline
\end{tabular}

\section{Third: Procedures to implement the research experiment The goal of the research experiment:}

The research experiment aims to measure the effectiveness of a multimediabased computer program in developing oral expression skills for fourth-graders in Arab private schools in Denmark.

\section{Research design}

In this research, the researcher used the experimental approach represented in studying the relationship between the independent variable

It is the teaching of the fourth unit using a computer program, and the dependent variable, which is the oral expression of non-Arabic speaking students in basic stage in Denmark. (Abu Allam, 2006) and (Jalal 2008) 


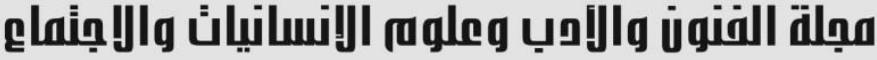 \\ Journal of Arts, Literature, Humanities and Social Sciences www.jalhss.com \\ Volume (54) July 2020 \\ العدد (54) يوليو 2020}

The researcher relied on a pre-test and a post-test for the study sample individuals. This curriculum is appropriate to the nature of the current research in terms of its attempt to verify the disclosure of the impact of the computer program on the development of oral expression in the curriculum of Arabic (accessible Arabic) among students of basic stage. The following figure shows the experimental design of the research steps:

\section{Research population:}

Society means "all individuals (or things, or elements) who have the same observable characteristics". (Abu Allam 2006, p. 154). Therefore, the original community of this research includes all the primary stage students in the Iqra School of the Danish Ministry of Education, who are enrolled in the first semester of the academic year 2017/2018, and they numbered (480) students divided into twelve departments Study according to the statistics of the Danish Ministry of Education. All ages ranged between $7-12$ years.

\section{The research sample:}

The primary study sample consisted of 40 male and female students divided into two groups, the experimental group and the control group. The intention was chosen for the following reasons:

1. Provides the necessary capabilities required to implement the computer program in this school, from smart boards, projectors, and computers in this school.

2. The high efficiency of the school in terms of teachers in applying active learning strategies and differentiated teaching, as the practical experience of Arabic language teachers is not less than twelve years.

3. The reputation read by the Iqra School in adopting active learning and e-learning strategies. The school has many benefits of excellence from the Danish Ministry of Education, as well as some of its teachers who are entitled to excellence in addition to having experts in e-learning.

4. The diversity of students within the school provides a kind of parity between the experimental and controlling groups in the social and economic levels, which facilitates the control of exotic variables that may affect the application of the research experience.

5. The researcher worked in the same school, which facilitates the supervision and follow-up processes in implementing the research experience.

6. The consent of one of the Arabic language teachers from the school staff to cooperate with the researcher to implement the research experience.

7. The cooperation of the school administration, its employees, the network administrator and the technical supervisor in providing all the necessary facilities. 


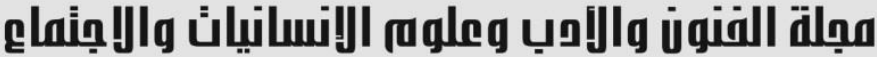

Journal of Arts, Literature, Humanities and Social Sciences

www.jalhss.com

Volume (54) July 2020

العدد (54) يوليو 2020

8. The school contains a number of classrooms for the basic stage studying the semester system, which allowed the researcher to choose one class as an experimental group and another as a control group.

Table (13): Distribution of the individuals of the study sample according to the group and the semester

\begin{tabular}{|c|c|c|c|c|c|c|}
\hline Group & Section & Class & Number & Percentage & Total & percentage \\
\hline Experimental & Semester & 4A & 20 & $\% 50$ & 20 & $\% 50$ \\
\hline Control & Semester & 4B & 20 & $\% 50$ & 20 & $\% 50$ \\
\hline
\end{tabular}

To ensure that the experimental and control groups are close to the age group The researcher monitored the students 'ages in the two groups, and then compared them using the T-Test after confirming the conditions of its application, to examine the significance of the difference between the average ages of the two groups.

The following table shows the results of the T-Test for the difference between the mean ages of the control and experimental groups.

Table (14) result of ( $\mathrm{T}$ ) test for the difference between the mean ages of the individuals in the study sample.

\begin{tabular}{|c|c|c|c|c|c|c|c|c|}
\hline \multirow{2}{*}{ Variable } & \multicolumn{3}{|c|}{ Experimental group } & \multicolumn{3}{|c|}{ Control group } & \multirow{2}{*}{ T } & Sig \\
\cline { 2 - 6 } & $\mathrm{N}$ & Mean & $\mathrm{SD}$ & $\mathrm{N}$ & Mean & SD & & \\
\hline Age & 20 & 17.8 & 0.407 & 20 & 17.67 & 0.479 & 1.161 & 0.250 \\
\hline
\end{tabular}

We conclude from the previous table that the value of (T) 1.161 is not statistically significant at the significance level 0.05 and therefore we conclude that there are no differences between the mean ages of the individuals of the two groups in the timelife variable.

-3In terms of class teacher and division:

The researcher paid attention to trying to teach the same teacher to the experimental and control groups in the semester system, and he succeeded in doing so with the cooperation of the School Board of Trustees and the school administration.

\section{Statistical processing:}

After completing the process of correcting the oral verbal expression test and tabulating the pre and post results, the Statistical Packages Program in Social Sciences (SPSS) was used in the statistical treatments necessary to process the data of this research and extract the results of its applications as follows: 


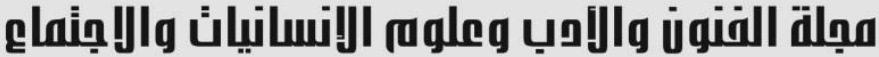

Journal of Arts, Literature, Humanities and Social Sciences

www.jalhss.com

Volume (54) July 2020

العدد (54) يوليو 2020

-Descriptive statistics calculations for the study sample individuals that provide a description of the characteristics of the sample in terms of repetition and percentage.

-Pearson correlation coefficient to measure the stability of the study tools.

- The $\mathrm{T}$ test for independent samples and the ANOVA test to measure the significant differences between the scores of students in the study groups.

Black's labs for earning and efficacy testing to measure the effectiveness of the computer program in developing oral expression skills.

\section{Results and discussion}

\section{First: The study results related to the first question}

"What is the proposed program for developing oral expression skills for fourthgraders"

To answer this question, the researcher used a computerized program to teach the Arabic language curriculum for fourth grade students for non-Arabic speakers in government schools affiliated with the Danish Ministry of Education in the capital, Copenhagen. The lessons to be taught to male and female students were chosen based on the skills reached by answering the first question, as the most important skills were chosen for the fourth primary class students and the lessons were chosen for the program in light of it, and the general framework of the program included: its objectives, content, organization, and methods Teaching, methods, activities and .evaluation

The program included three lessons taught in various ways and means, which are the basis for building the program, through 15 lessons for the two samples: control and experimental. 3-4 sessions per week for listening (speaking comprehension) and speaking (verbal expression) skills. The reliance on the computer to teach the program came due to the great role that educational technologies play, as many studies that have been researched in the field of the impact of educational techniques and means, and their role in educational situations and reaching a high degree of influence both in the psychological, educational or educational aspect, and that lies. In it (Ismail, 2001). 


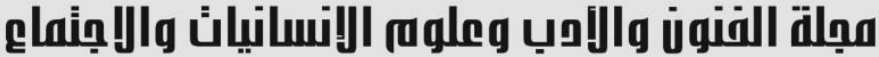

Journal of Arts, Literature, Humanities and Social Sciences

www.jalhss.com

Volume (54) July 2020

العدد (54) يوليو 2020

1. It raises students' attention to lessons, increases their interest in them and their interest in studying.

2. Make education more thoughtful and consistent in the minds of students.

3. It develops in learners the curiosity, and creates in them a desire for achievement and perseverance in learning.

4. It strengthens the learner's sense of the importance of his knowledge gained through his experiences and his independent effort.

5. Contributes to the values of respect, cooperation and responsibility.

6. The element of confidence of the student and the teacher is strengthened.

7. Provides teacher and learner time and facilitates teaching and learning.

8. A variety of forms of self-learning is provided to learners.

9. It provides a good opportunity to realize the facts by linking previous experiences with new experiences.

\section{Second: The study results related to the second question}

Are there statistically significant differences at the level of significance $(\alpha \leq 0.5)$ between the mean scores of the experimental group students and the mean scores of the control group students in the immediate oral expression skills test after the experiment?

To answer the previous question, the researcher put the following hypothesis: "There are no statistically significant differences at the level of significance $(\alpha \leq 0.5)$ between the average scores of students of the experimental group and the average score of the students of the control group in the test of immediate verbal expression skills after conducting the experiment" and to test the validity of this hypothesis was Building a test to measure oral expression skills, and after applying the test before applying, the lessons chosen were taught by the computerized program, followed by applying the test after application, where a balance was made between the students of the experimental group and the students of the control group by calculating the averages for the grades, and the curves $\mathrm{F}$ standard, calculate the t-test to identify the significance of differences between the Mediterranean. Table No. (15) illustrates this. 


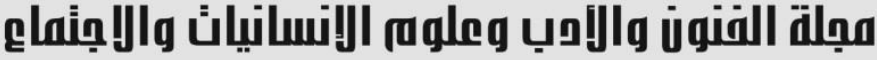 \\ Journal of Arts, Literature, Humanities and Social Sciences \\ www.jalhss.com \\ Volume (54) July 2020 \\ العدد (54) يوليو 2020}

Table No. (15): Significance of the differences between the mean scores of the experimental group students and the mean of the controlling group scores in the test of immediate oral expression skills after performing the experiment

\begin{tabular}{|c|c|c|c|c|c|c|}
\hline Group & $\mathrm{N}$ & $\mathrm{M}$ & SD & $\mathrm{T}$ & $\begin{array}{l}\text { Sig (2- } \\
\text { tailed) }\end{array}$ & Sig \\
\hline Experimental & 20 & 81.36 & 3.79 & \multirow[t]{2}{*}{9.521} & \multirow[t]{2}{*}{0.005} & \multirow[t]{2}{*}{ Sig } \\
\hline Control & 20 & 54.17 & 8.72 & & & \\
\hline
\end{tabular}

It is clear from the previous table that there are significant differences with statistical significance at the level of significance $(0.01)$ between the average scores of students in the experimental and control groups after experimenting with the computer program in testing the skills of immediate oral expression after conducting the experiment, which indicates the rejection of the previous hypothesis which stated that " There were no statistically significant differences at the level of significance $(\alpha \leq 0.5)$ between the average score of the experimental group students and the mean score of the control group students in the immediate oral expression skills test after the experiment was conducted.

The researcher attributes the superiority of the experimental group to several reasons, the most important of which are:

1. The application of the computer program had a significant impact on the male and female students in the experimental group.

2. Proper preparation of the computer program related to the chosen lessons in a way that is compatible with the educational goals of the program lessons.

3. Linking the computer program to the Arabic language course, and the practical application of all program lessons led to increased interaction between the teacher and the learner on the one hand and between the learner and the content of the proposed program on the other hand.

4. The computer program with its educational lessons fits the student's preferences.

\section{Third: The study results related to the third question}

"What is the effectiveness of the proposed computer program in developing oral expression skills among fourth-grade basic students who do not speak Arabic?"

To answer this question, the researcher built a test to measure oral expression skills, and after applying the test before applying the lessons, the chosen lessons were taught by the computer program, followed by applying the test immediately after the 


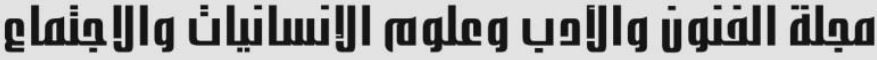 \\ Journal of Arts, Literature, Humanities and Social Sciences \\ www.jalhss.com \\ Volume (54) July 2020 \\ العدد (54) يوليو 2020}

experiment was conducted, where a balance was made between the performance of the students of the experimental sample in the pre-test, And their performance in the immediate test after conducting the experiment through calculating the average scores, the standard deviation, and the calculation of the test (T) to identify the significance of the differences between the two averages using the Black equation, and Table No. (16) illustrates this.

Table No. (16): The adjusted gain value of the oral expression for the experimental group

\begin{tabular}{|c|c|}
\hline \multicolumn{2}{|c|}{ Oral expression skills test } \\
\hline Average score of the experimental group in the tribal application & 38.9 \\
\hline $\begin{array}{c}\text { Average score of experimental group in immediate application } \\
\text { after experiment }\end{array}$ & 81.36 \\
\hline The Great End & 90 \\
\hline Gain rate ratio & 1.214 \\
\hline
\end{tabular}

It is clear from the previous table that the ratio of the adjusted gain for the oral expression test is 1.214, and it is considered a high rate of gain if compared to the minimum for the modified ratio of the blackberry gain, which is (1), which means that the program has an impact on developing oral expression skills among fourth-grade students.

Thus, it can be said that the superiority of the experimental group in the immediate application after conducting the experiment on the tribal application is due to several factors, including: the ease of displaying information through the computer program in the form of small parts, which makes it easier for the learner to form information on his mind in line with his cognitive structure and allow him to deal with the stores In a suitable sequence for it, the software allows creating a flexible educational environment that requires the learner to make decisions, and to allow the opportunity to highlight its various capabilities and benefit from computerized content in a way that makes uses meaningful.

\section{Recommendations and proposals}

Based on the results of the current study, the following recommendations and suggestions can be made:

1. The necessity of employing computerized programs in teaching Arabic to non-native speakers, especially oral expression.

2. The need for verbal expression for non-Arabic speakers to have its own decision attached to a teacher's guide.

3. The need to focus on language skills in general, and oral expression skills in particular, and to analyze these skills, and work to develop them. 


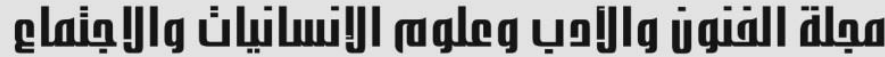

Journal of Arts, Literature, Humanities and Social Sciences

www.jalhss.com

Volume (54) July 2020

العدد (54) يوليو 2020

4. Taking into account students' inclinations regarding choosing multiple subjects to express them orally.

5. Encouraging students to verbal expression through school broadcasts and various means.

6. Conduct competitions for oral expression among students and motivate them to do so.

7. The necessity of linking the teaching of oral expression to other branches of the Arabic language, such as reading, archives and grammar.

8. Encouraging and training non-native speakers of Arabic language to use multimedia technology and its multiple software that develops oral expression skills and other language skills for students.

9. Training students teachers in colleges of education in the use of this technology and its media and software in teaching and learning Arabic for non-native speakers and following them in how to benefit from them during the period of practical education.

10. The effectiveness of a proposed multimedia computer program in developing oral expression among non-native speakers of Arabic at the secondary level in the Kingdom of Denmark.

11. The effect of using multimedia software in teaching Arabic to nonnative speakers on developing oral expression skills among adult Arabic language learners in Arabic teaching centers for non-native speakers in the Kingdom of Denmark.

12. Comparing multiple computer media and its software with other educational technology media, such as video, for example, in terms of its impact on developing oral expression among non-native Arabic learners.

13. Difficulties faced by non-native speakers of Arabic when using multiple and superior computer media and impeding them in the performance of their message in teaching and learning. 


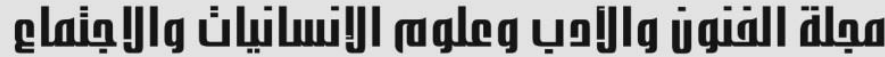

Journal of Arts, Literature, Humanities and Social Sciences

www.jalhss.com

Volume (54) July 2020

العدد (54) يوليو 2020

\section{References}

1. Ismail, the curious Zahir. (2001). Information technology and education modernization, Cairo, the world of books.

2. Ismail, Zakaria (1991): Methods of Teaching Arabic Language, Alexandria, Dar Al-Maarefa Al-Jamiiah.

3.- Al-Lokani, Ahmed Hussein and Al-Jamal, Ali. (1996) Dictionary of cognitive educational terms in curricula and teaching methods, first edition, Cairo: Books World.

4. Hope. (2014). Foundations of Oral Expression, Al-Madinah International University Journal for Educational Sciences - Egypt, 1 (98).

5. Al-Bishri, Muhammad Bin Shadid (2007): Weaknesses in Oral Expression Skills and a Proposed Program for its Treatment, PhD Thesis, Imam Bin Masoud Islamic University, p. 14.

6. Rahi, Qahtan Fadl, and Hassan Thabet Rashid. (2011). Using computers to determine the optimal teaching methods for student education. Journal of the Kufa Studies Center, 1 (21).

7. Rahmani, Sakina. (2017). Methods of teaching oral expression subject in the light of the competency approach (fourth year primary model) ( $\mathrm{PhD}$ thesis).

8. Al-Sufouh, Samir Sayel Ali / Nasr, Hamdan Ali. (2007). Evaluating the oral expression skills of the ninth grade students and building a proposed program in light of the results. Unpublished doctoral thesis.

9. Al-Swairki, Muhammad Ali. (2005). The effect of using a program based on language games on the development of language structures and oral expression skills among fourth-grade primary students in Jordan. Journal of Educational and Psychological Sciences. 7 (3). 69-94.

10. Al-Swairki, Muhammad Ali (2005). The effect of using a program based on language games on developing the language patterns and oral expression skills of fourth grade students in Jordan. Unpublished PhD thesis, Arab University for Graduate Studies.

11. Al-Smadi, Hussein Abdullah. (2018) The impact of a computerized program to develop oral expressive language skills among children with learning difficulties, Journal of Scientific Research in Education, Ain Shams University - Girls College of Arts, Sciences and Education 19 (6), 169-187

12. Abdel Hamid, Abdel Aziz Tolba. (2013). A suggested program to train student teachers on the use of Point Power presentations in the design and production of multimedia educational software and develop their attitudes towards computer use in education, The Fourteenth Scientific Conference (Curricula of Education in the Light of Performance Concept), Volume One, Guest House, Ain Shams University.

13. Abdel-Wahab, Ahlam Tarkhan Ahmed, Haredi, Iman Ahmed, Issa, Ahmed Mohamed. (2017). The effectiveness of teaching using the voice input to develop oral expression skills among primary first-grade pupils from basic education, Journal of Arab Studies for Education and Psychology, 36 (104), 1-39. 


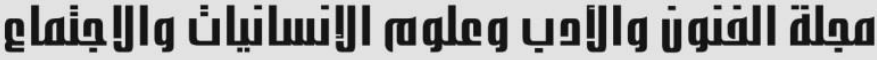 Journal of Arts, Literature, Humanities and Social Sciences www.jalhss.com

14. Abdel Wahab, Mohamed Mahmoud. (2016). The effectiveness of an inverted elearning strategy based on e-books in developing some reading comprehension skills among students of the Arabic Language Teaching Institute for non-native speakers of the Islamic University, Journal of Education, 69 (149), 1-35.

15. Othman, Badr Al-Din Mahjoub. (2014). Employing modern methods of educational technology in the educational process, Journal of Science and Technology, 15 (4).

16. Asr, Hosni Abdel Bari. (1997). Issues in teaching and teaching Arabic. Alexandria: Modern Arab Office.

17. Ammar, Sam. (2002). Modern trends in teaching Arabic. First edition, Beirut: The Resala Foundation.

18. The stranger, Zahir, Sharjah. ((2001. The effectiveness of using internet services in developing knowledge aspects and supporting research performance among masters students in education, educational and social studies, a periodical journal, volume 7, number three, faculty of education, Helwan University, Egypt.

19. Fleet, full beauty. (2002). A proposed program in additional readings to develop some written expression skills for ninth grade students in Gaza governorates, unpublished master's thesis, Al-Azhar University, College of Education.

20. Al-Qalamji, Uday Rashid Muhammad. (2016). Building a standard for measuring oral expression among primary school students. Journal of Educational and Psychological Research, 2 (48) and 291-314.

21. Keita, Jacarija, Ismail, and Muhammad Zaid. (2016). Suggested strategy to develop oral expression skills in Arabic for Malaysian students, Journal of Humanities and Social Sciences, 194 (3420), 1-14

22. Muhammad, Ali Abdel-Moneim Ali. (2008). The effectiveness of using language games in developing creative oral expression skills for primary school pupils, Journal of the College of Education, 3 (9), 183-199.

23. Al-Masry, Youssef Saeed Mahmoud (2006): The effectiveness of a multimedia program in developing and retaining writing skills for basic eighth graders. A magister message that is not published. Curricula and Teaching Methods Department, Specialization in Educational Technology, Islamic University. Gaza.

24. The Arab Organization for Education, Culture and Science. ((2009. Modern Technologies in Teaching the Arabic Language, a study presented in a symposium entitled: The use of modern technologies in teaching the Arabic language to speakers of other languages, held at the Khartoum International Institute of the Arab Organization for Education, Culture and Science - League of Arab States, on December 29, Africa International University Hall .

25. Miloud, Ghazali. (2018). Obstacles in the oral expression activity in the primary stage.

26. Al-Hashemi, Abd al-Rahman. (2005). Expression: its philosophy, reality, teaching, methods of correction. First edition, Oman: Dar Al-Manhaj for Publishing and Distribution. 